\title{
Short-term effects of different pasture improvement treatments on the physical quality of an andisol
}

\author{
J. Dörner ${ }^{1,2 *}$, F. Zúñiga ${ }^{3}$ and I. López ${ }^{2,4}$ \\ ${ }^{1}$ Instituto de Ingeniería Agraria y Suelos, Facultad de Ciencias Agrarias, Universidad Austral de Chile , Valdivia, Chile. ${ }^{2}$ Centro \\ de Investigación en Suelos Volcánicos, Universidad Austral de Chile, Valdivia, Chile. ${ }^{3}$ Magíster en Ciencias del Suelo, Escuela \\ de Graduados, Facultad de Ciencias Agrarias, Universidad Austral de Chile, Valdivia, Chile. ${ }^{4}$ Instituto de Producción Animal, \\ Facultad de Ciencias Agrarias, Universidad Austral de Chile, Valdivia, Chile. Corresponding author: josedorner@uach.cl
}

\begin{abstract}
The improvement of degraded pastures is important for increasing pasture herbage mass and animal production in southern Chile. While research has normally focused on how animal treading affects soil compaction, no major work has yet been done to define the impact of pasture improvement managements on soil physical functions, particularly when the initial situation is a degraded pasture. Thus, the aim of this study is to define the shortterm effects of different pasture improvement managements on the physical quality and related processes of a volcanic ash soil. Four treatments were defined: two tilled, fertilized and seeded plots (T1 and T2), one non-tilled and non-fertilized plot (T3) and one non-tilled and fertilized plot (T4), all of which were compared to the initial situation of a highly degraded pasture (IS). Undisturbed soil samples were collected $(1-10 \mathrm{~cm})$ and the volumetric water content and temperature was continuously monitored at the $10 \mathrm{~cm}$ depth. The short-term effects of pasture improvement managements on soil physical quality and related processes differed in relation to the treatment method. As compared to the non-tilled plots, the aggregate destruction after tillage induced an increase in the water holding capacity, but a decrease in the air capacity and pore-continuity values due to grazing. The physical quality assessed by the S-Index reflected a good soil structural quality $(\mathrm{S}>0.035)$. The tilled plots presented a higher S-Index as compared to the non-tilled plots, which is related to a slightly lower mechanical strength and larger water holding capacity. The latter also increased due to tillage and was positively correlated to pasture yields during the first intensive soil drying. Soil temperature differences between treatments were assessed and can be related to the higher water contents in the tilled plots and the presence of broad-leaf species in the non-tilled pastures. Finally, in order to properly understand how the implementation of pasture improvement managements affects the soil physical quality and related processes, long-term studies are required.
\end{abstract}

Keywords: Soil physical properties, volcanic ash soil, pasture improvement managements 


\section{Introduction}

Soil physical quality can be characterized in relation to its hydraulic (i.e., saturated hydraulic conductivity) and/or mechanical (i.e., soil strength) properties. This concept allowed us to evaluate agricultural management's effects on soil physical functions (e.g., water storage capacity), using "indicator" soil parameters to quantify the level or degree of quality (Reynolds et al., 2009; Horn and Fleige, 2009). Soils with good physical quality for agricultural management are commonly described as those with a well-developed soil structure, implying good water infiltration and no runoff (hydraulic conductivity values $>20 \mathrm{~cm} \mathrm{~d}^{-1}$ ), good aeration and gas exchange (air conductivity values over $10^{-4} \mathrm{~cm} \mathrm{~s}^{-1}$ ), rootability (penetration resistances lower than $2000 \mathrm{kPa}$ at field capacity) and workability (Dexter, 2004, Horn and Fleige, 2009).

Many scientists have already described how grazing affects soil physical quality; however, little work has been done to evaluate natural soil recovery (Dec et al., 2012) and/or the effect of pasture improvement managements (PIM) on soil physical functions. The main consequences of grazing are soil compaction due to animal trampling (Greenwood and McKenzie, 2001; Drewry, 2006), leading to changes in soil pores, conductivity values; Reszkowska et al., 2011;Dec et al., 2012) and, consequently, to an increase in the soil's susceptibility to erosion. Natural soil recovery after grazing or the implementation of PIM to recover soil physical functions depends mainly on soil resilience, i.e., the ability of the soil to counteract stresses and recuperate e.g., soil pore functions (Dörner et al.;2012) in a defined period of time. Dec et al. (2012) evaluated the temporal variability of mechanic and hydraulic properties in a Duric Hapludand. They concluded that pores responsible for air exchange are easy to deform when the soil is susceptible to mechanical stresses (due to tillage before seeding and as a consequence of compaction after grazing). However, the same pores were able to recover when the grazing frequency decreased, which can be ascribed to wetting and drying cycles, soil microbiological activity and, the consequently high resilience capacity of Andisols (Dörner et al., 2012)

In southern Chile, $91 \%$ of the 1.3 million ha of pasture are naturalised (INE, 2007). A naturalised pasture has been defined as a pasture composed of native and non-native species that spontaneously grow together (Butler et al., 1997). A total of $48 \%$ of the naturalised pastures are only under grazing, and do not receive any type of fertilisers to compensate for the nutritional losses (INE, 2007). Therefore, these pastures present a degree of degradation, which is represented in a low annual yield between 3 to $5 \mathrm{t}$ DM ha-1, instead of 12 to $14 \mathrm{t} \mathrm{DM} \mathrm{ha}^{-1}$ (Balocchi and López, 2007). Thus, pasture degradation due to poor pasture management has both environmental and social consequences (Amtmann et al., 1999). Therefore, improving pastures is a major concern that must be approached in a sustainable manner. As environmental standard requirements for animal production systems and improved pasture species productivities increase, the balance and rational use of productive resources must also improve (Havlin et al., 2005).

Pasture improvement managements in southern Chile, particularly those in volcanic ash soils, include the fertilization of degraded pastures (e.g. to improve $\mathrm{pH}$ deficiencies without soil ploughing) and/or the sowing of new pastures (which includes soil tillage and fertilization). These techniques have different impacts on the soil physical quality, since, for example, tilling breaks the soil structure, affecting soil pore functions, while fertilization without ploughing maintain and even improve soil physical parameters (Dörner et al., 2012). The consequences of grazing on soil structural properties and their related pore-functions have been evaluated in volcanic soils (Dec et al., 2012); however, no work has yet been done to define 
the impact of PIM on soil physical functions, particularly, when the initial situation is a highly degraded pasture. This is relevant, since Andisols present exceptional physical properties, such as a bulk density of $<0.9 \mathrm{Mg} \mathrm{m}^{-3}$, a well-defined interand intra-aggregate pore system (Dörner et al., 2012), stable soil aggregates (Baumgarten et al., 2013), and a high resilience capacity (Dörner et al., 2012). The hypothesis of this study is that the pasture improvement management (PIM) affects soil physical quality differently in the short term, so that, while the soil tillage and seeding improve the water holding capacity and decrease the mechanical strength, the non-tillage management keeps the pore continuity as compared to the tilled plots. Therefore, this study aimed to determine the short-term effects of different PIM, with and without tillage, on the physical quality and related processes (topsoil water content and temperature dynamics) of a volcanic ash soil.

\section{Material and Methods}

\subsection{Soil and management}

The evaluation was carried out at the Agricultural Experimental Station (Santa Rosa), Universidad Austral de Chile, Valdivia, Chile (39 $48^{\prime}$ S, $73^{\circ} 15^{\prime}$ E, $12 \mathrm{~m}$ a.s.1.). The soil is a moderately deep Andisol (Duric Hapludand, soil Serie Valdivia according to CIREN, 2003) with a silty loam texture in the first $30 \mathrm{~cm}$, which became coarser (sandy loam till sandy) in deeper horizons $(30-120 \mathrm{~cm})$. The topography is complex till softly wrinkled, with slope gradients between 5 and $8 \%$ (CIREN, 2003). However, on the experimental site, the slope gradient was $<2 \%$. The climate is humid temperate (Amigo and Ramírez, 1998), with an average annual temperature of $12{ }^{\circ} \mathrm{C}$ with reduced thermal amplitude as a consequence of the short distance between the sea and the lakes. The average annual precipitation is $2,500 \mathrm{~mm}$ withheavy rainfalls concentrated in July.
The experiment was conducted on a degraded pasture, mainly composed of Agrostis capillaris, Holcus lanatus, Hypochaeris radicata and Anthoxanthum odoratum. In general, a low fertility level was observed (Flores et al., 2013), particularly due to low levels of $\mathrm{K}\left(68 \mathrm{cmol}^{+} \mathrm{kg}^{-1}\right)$, the total bases exchange ( $\mathrm{K}, \mathrm{Na}, \mathrm{Ca}$ and $\mathrm{Mg}$ was $70.5 \mathrm{cmol}^{+} \mathrm{kg}^{-1}$ ) and a high $\mathrm{Al}$ saturation (13\%), which is defined as the exchange $\mathrm{Al}$ over the effective cation exchange capacity. The soil's condition explains the presence of the previously mentioned plant species, since they are aluminium tolerant (López et al., 1997). In order to improve degraded pastures, four treatments were applied (Table 1): Lolium perenne + Trifolium repens (T1), multiple pasture species (T2) composed of Bromus valdivianus, Holcus lanatus, Lolium perenne, Dactylis glomerata and Trifolium repens, naturalized pasture without fertilization (T3) and naturalized pasture with fertilization (T4). The experiment was designed as a randomized complete block design with 3 replicates for each treatment. Therefore, the experiment was conducted in 12 plots $(20 \times 20 \mathrm{~m})$ with a total area of $4,800 \mathrm{~m}^{2}$.

\subsection{Field measurements and soil samplings}

To characterize how the PIM affected water content and temperature of the soil, TDRs (3 repetitions, SM200 soil moisture sensors, Delta T Devices, Burwell Cambridge, United Kingdom) and temperature sensors (Pt100 soil temperature sensors, ZIEHL Industrie Elektronik $\mathrm{GmbH}+$ Co KG, Stuttgart, Germany) were installed in December 2010 at $10 \mathrm{~cm}$ depths in each treatment. The TDR sensors were calibrated following the technique proposed in the SM200 User Manual 1.1 (Delta-T Devices Ltda., 2006). Additionally, a rain gauge was placed at each sampled site. The measurements took place every $30 \mathrm{~min}$ between January 2011 and January 2012. 
Table 1. General description of improvement managements for the degraded pasture.

\begin{tabular}{|c|c|c|c|c|}
\hline Treatments & Soil and grazing managements & Soil fertilization & Sown species & PR and $\theta$ values \\
\hline IS: Initial condition & Soil tillage and grazing was not conducted. & Null & Null & $\mathrm{PR} 1=1511 \pm 31 / \square=50$ \\
\hline $\mathrm{T} 1$ & $\begin{array}{l}\text { March 2010. Weed control, offset disc harrov } \\
\text { (five times), field cultivator (once). } \\
\text { Four grazing events were conducted. }\end{array}$ & $\begin{array}{l}\text { wN: } 120 \mathrm{~kg} \mathrm{ha}^{-1} ; \mathrm{P}: 120 \mathrm{~kg} \mathrm{ha}^{-1} \cdot \mathrm{K}^{-1} \\
120 \mathrm{~kg} \mathrm{ha}^{-1} ; \mathrm{CaCO}_{3}: 2000 \mathrm{~kg} \mathrm{ha}^{-1} \text {. }\end{array}$ & $\begin{array}{l}\text { Lolium perenne }\left(25 \mathrm{~kg} \mathrm{ha}^{-1}\right) ; \text { Trifolium } \\
\text { repens }\left(5 \mathrm{~kg} \mathrm{ha}^{-1}\right)\end{array}$ & $\begin{array}{l}\mathrm{PR} 1=1176 \pm 47 / \square=45 \\
\mathrm{PR} 2=1278 \pm 16 / \theta=42\end{array}$ \\
\hline $\mathrm{T} 2$ & $\begin{array}{l}\text { March 2010. Weed control, offset disc harrov } \\
\text { (five times), field cultivator (once). } \\
\text { Five grazing events were conducted. }\end{array}$ & $\begin{array}{l}\text { wN: } 120 \mathrm{~kg} \mathrm{ha}^{-1} ; \mathrm{P}: 120 \mathrm{~kg} \mathrm{ha}^{-1} . \mathrm{K}^{-} \\
120 \mathrm{~kg} \mathrm{ha}^{-1} ; \mathrm{CaCO}_{3}: 2000 \mathrm{~kg} \mathrm{ha}^{-1} \text {. }\end{array}$ & $\begin{array}{l}\text { Bromus valdivianus }\left(27 \mathrm{~kg} \mathrm{ha}^{-1}\right) \text {; Lolium } \\
\text { perenne }\left(9 \mathrm{~kg} \mathrm{ha}^{-1}\right) ; \text { Dactylis glomerata } \\
\left(4 \mathrm{~kg} \mathrm{ha}^{-1}\right) \text {; Trifolium repens }\left(5 \mathrm{~kg} \mathrm{ha}^{-1}\right)\end{array}$ & $\begin{array}{l}n \mathrm{PR} 1=1259 \pm 32 / \theta=40 \\
\mathrm{PR} 2=1254 \pm 5 / \theta=39\end{array}$ \\
\hline T3 & $\begin{array}{l}\text { Soil tillage was not conducted } \\
\text { Four grazing events were conducted. }\end{array}$ & Null & Null & $\begin{array}{l}\mathrm{PR} 1=1330 \pm 27 / \theta=41 \\
\mathrm{PR} 2=1594 \pm 33 / \theta=39\end{array}$ \\
\hline $\mathrm{T} 4$ & $\begin{array}{l}\text { Soil tillage was not conducted. } \\
\text { Five grazing events were conducted. }\end{array}$ & $\begin{array}{l}\mathrm{N}: 120 \mathrm{~kg} \mathrm{ha}^{-1} ; \mathrm{P}: 120 \mathrm{~kg} \mathrm{ha}^{-1} \cdot \mathrm{K}: \\
120 \mathrm{~kg} \mathrm{ha}^{-1} ; \mathrm{CaCO}_{3}: 2000 \mathrm{~kg} \mathrm{ha}^{-1} .\end{array}$ & Null & $\begin{array}{l}\mathrm{PR} 1=1511 \pm 31 / \theta=50 \\
\mathrm{PR} 2=1474 \pm 43 / \theta=47\end{array}$ \\
\hline
\end{tabular}

The $\mathrm{N}$ fertilization was applied 3 times. The stocking rate was 25 sheep/plot. PR1 and PR2 = penetration resistance $(\mathrm{kPa})$ before and after the first grazing event. $\theta=$ Volumetric water content $(\%)$.

Disturbed and undisturbed soil samples for physical analyses were collected from 1-10 cm depths in August and December, 2010. The depth was selected in order to register the impact of soil management, vegetation and grazing, and also in an attempt to avoid any mechanical disturbance when collecting undisturbed soil samples. The sampling conducted in August was used as a control (initial situation of degrade pasture, grazed during the last 30 years: IS) to evaluate the impact of the PIM on soil physical quality. During the second sampling (December), after four and five grazing events (Table 1), field measurements were conducted, and soil samples were collected in all treatments. The penetration resistance (PR) was measured in the field (10 determinations for each replicate) using a penetrometer (06.01 Hand Penetrometer, Eijkelkamp, Agrisearch Equipment, Giesbeek, The Netherlands) to characterize the soil mechanical strength in the first 10 $\mathrm{cm}$ of soil. Additionally, the volumetric water content was registered (10 repetitions for each treatment) using a TDR (WET Sensor, Delta T Devices, Burwell Cambridge, United Kingdom). The disturbed samples, collected with a spade and carefully placed in plastic boxes, were used for determination of soil organic matter content and particle density, and to select soil aggregates to measure its tensile strength. The undisturbed samples were collected in metallic cylinders, and used to measure hydraulic and mechanical properties as described below.

\subsection{Soil texture, particle density and organic matter content}

The soil samples were air-dried and then sieved to a $2 \mathrm{~mm}$ size. The soil texture was determined using the hydrometer method after the organic matter was destroyed using $\mathrm{H}_{2} \mathrm{O}_{2}$ (Day, 1965). Thereafter, cementing agents were eliminated with $\mathrm{Na}_{2} \mathrm{~S}_{2} \mathrm{O}_{4}$, $\mathrm{Na}_{3} \mathrm{O}_{7} \mathrm{C}_{6} \mathrm{H}_{5}(0.3 \mathrm{M})$ and $\mathrm{CH}_{3} \mathrm{COONa}(1 \mathrm{M})$ and clay was dispersed with $\mathrm{Na}_{4} \mathrm{P}_{2} 0_{7}(0.1 \mathrm{~N})$. The particle density was measured with the pycnometer method, using a vacuum (Klute, 1986). Organic carbon was determined using Walkley and Black's method (1934).

\subsection{Mechanical properties}

The soil mechanical properties were measured at different scales; they were measured at the soil horizon 
scale by measuring the penetration resistance in the field. At the aggregate group scale, they were measured by evaluating the consolidation curve of structured samples. And, finally, the soil mechanical properties of single aggregates were measured by recording their tensile strength.

The consolidation curve was measured using an odometer with drainage. The undisturbed samples $\left(\mathrm{n}=12 ; 120 \mathrm{~cm}^{3} ; \mathrm{h}=3.0 \mathrm{~cm}\right.$, and $\mathrm{d}=7.1 \mathrm{~cm}$ ) were measured at the water content equivalent to a water potential of $-6 \mathrm{kPa}$. The samples were first stressed by static loading $(6,12,25,50,100,200$ and $400 \mathrm{kPa})$ for 6 minutes and thereafter, the stresses $\left(\sigma_{\mathrm{n}}\right)$ were removed until 200, 100,50, 6 and $1 \mathrm{kPa}$ were reached. Soil deformation was measured during the experiment (0.05 $\mathrm{mm}$ accuracy) and the precompression stress (Pc) was defined in accordance with Casagrande, using the mathematical methodology proposed in Baumgartl and Köck (2004).

The indirect tensile strength of aggregates (AS) was also measured (Crushing Test according to Dexter, 1988). The water-saturated aggregates were equilibrated at $-6 \mathrm{kPa}$ of their water potential. Thereafter, they were weighed and crushed between two splits as a result of ain increasing load on the upper split. The rising loads were reached by increasing the amount of water in the container on the upper split. The load necessary to crush every aggregate was noted (amount of water) and used to calculate the aggregate strength. Finally, aggregates were oven dried at $105^{\circ} \mathrm{C}$ for $24 \mathrm{~h}$ to determine the gravimetric water content.

\subsection{Hydraulic properties}

The hydraulic properties were determined in order to evaluate capacity (water retention curve and derived pore size distribution) and intensity (air conductivity) parameters (Horn and Kutilek, 2009). The authors mentioned that while the first defines a general status (bulk density), the second quantifies the functionality of the pore system.
The water retention curve (WRC) and air conductivity $\left(k_{l}\right)$ were measured in undisturbed samples $(\mathrm{n}=12 ; 230$ $\mathrm{cm}^{3} ; \mathrm{h}=5.6 \mathrm{~cm}$, and $\mathrm{d}=7.2 \mathrm{~cm}$ ), simultaneously. The samples were first carefully saturated from beneath, and then, drained at water potential values of $-1,-2,-3,-6$, $-15,-33,-50 \mathrm{kPa}$. From saturation and throughout the different water potentials, the water content and $k_{l}$ (only at $-6,-15,-33,-50 \mathrm{kPa}$ ) were recorded respectively with an electronic balance (Precisa, $0.01 \mathrm{~g}$ accuracy) and air flow meter $(0.01 \mathrm{~L} / \mathrm{s}$ accuracy; details about the air flow meter can be found in Dörner and Horn 2006).

The measured values of the WRC were used to define the van Genuchten parameters (van Genuchten, 1980). These parameters were used to calculate the S physical quality index, which is equal to the slope of the soil water retention curve at its inflection point (Dexter, 2004).

The air conductivity $\left[\mathrm{cm} \mathrm{s}^{-1}\right]$, which was measured according to Dörner and Horn (2006), was used to calculate the air permeability $k_{\alpha}\left[\mu \mathrm{m}^{2}\right]$ as:

$$
k_{a}\left(\varepsilon_{a}\right)=k_{l}\left(\varepsilon_{a}\right) \cdot \frac{\eta}{\rho_{1} \cdot g}
$$

where $\eta$ is the air viscosity $\left[\mathrm{g} \mathrm{s}^{-1} \mathrm{~cm}^{-1}\right], \rho_{1}$ is the air density $\left[\mathrm{kg} \mathrm{m}^{-3}\right], \varepsilon_{\alpha}$ is the air-filled porosity $\left[\mathrm{m}^{3} \mathrm{~m}^{-3}\right]$ and $g$ is the gravitational acceleration $\left[\mathrm{m} \mathrm{s}^{-2}\right]$. Both air viscosity and density were corrected according to temperature $\left[{ }^{\circ} \mathrm{C}\right]$.

The $\varepsilon_{\alpha}$ a was calculated from the measured WRC as the difference between total porosity and the volumetric water content at a given matric potential. Additionally, two pore continuity indices $\left(C_{2}\right.$ and $C_{3}$, both in $\left.\mu \mathrm{m}^{2}\right)$, proposed by Groenevelt et al. (1984) and used by Ball et al. (1988), Dörner and Horn (2006) were calculated from the ratio of air permeability $\left(k_{\alpha}\right)$ and air-filled porosity $\left(\varepsilon_{\alpha}\right)$ and the ratio of $k_{\alpha}$ and $\varepsilon_{\alpha}{ }^{2}$. These indices were defined for pairs of values, as follows: 


$$
C_{2}=\frac{k_{a}}{\varepsilon_{a}}
$$

$$
C_{3}=\frac{k_{a}}{\varepsilon_{a}^{2}}
$$

Groenevelt et al. (1984) mentioned that soils presenting similar pore-size distribution and pore continuity have analogue values of $C_{2}$. On the other hand, soils with similar values of $C_{3}$ only have analogue pore-size distribution. Thus, differences between $C_{2}$ and $C_{3}$ are related to differences in pore continuity, independent of the pore-size distribution (Groenevelt et al., 1984; Ball et al., 1988; Dörner and Horn, 2006). Additionally, Ball et al. (1988) suggested that $k_{\alpha}$ and $\varepsilon_{\alpha}$ may be related as follows:

$\log k_{a}=\log (M) \cdot N \log \left(\varepsilon_{a}\right)$

where, $\mathrm{M}$ and $\mathrm{N}$ are empirical parameters: $\mathrm{N}$ is a pore continuity index, which reflects the increase of $k_{\alpha}$ with increasing $\varepsilon_{\alpha}$, or the decrease of pore tortuosity and surface area with the increasing fraction of pores available to flow (Ball et al., 1988). Ball et al. (1988) also proposed that an estimate (equation 5) of blocked airfilled pore space $\left(\varepsilon_{b}\right)$ may be derived from equation 4 .

$\varepsilon_{b}=10^{(-\log M) / N}$

\subsection{Statistics}

Averages and standard errors for the different variables of each soil property were calculated. The analysis of variance $(p \leq 0.05)$ was applied to test how the treatments affected soil hydraulic and mechanical properties. The differences of means were assessed with the LSD test $(p \leq 0.05)$. Linear regressions were also determined. When the data was not normally distributed, box plots were used. Each box plot contains information about the mean (+ symbol) and median values (black line across the box), lower and upper hinges (defined as the 25 th and 75 th percentiles), minimum and maximum values and outliers (displayed as little squares). In addition, the notches presented in each box plot show the $95 \%$ confidence interval of differences between medians.

\section{Results}

3.1. Soil water content and temperature dynamics in the field

The soil temperature's daily and annual cycle was clearly reflected in all treatments (Figure 1). Average temperatures in tilled plots (T1 and $\mathrm{T} 2$ ) were $1.4^{\circ} \mathrm{C}$ higher than those observed in the non-tilled plots (T3 and T4). The tilled plots reached the highest maximum temperature values. The rainfall, which was concentrated between April and October, reached $1,880 \mathrm{~mm}$, with maximum daily values of $91 \mathrm{~mm}$ on April and $72 \mathrm{~mm}$ on August of 2011. After October the amount of rainfall decreased.

Water content dynamics differed between treatments and reflected the occurrence of wetting-drying cycles throughout the year (Figure 2). The highest soil water contents were registered during the winter (June-September), whereas the lowest ones were in December/January, as soon as the highest temperatures (Figure 1) were reached. During winter, the observed water contents in T1 $(64 \%)$ and T2 (65\%) were greater than those values registered in T3 $(58 \%)$ and T4 (63\%). During the first intense drying cycle (from October to November, 2011) the soil water content was higher in T1 (23\%), T2 (23\%) and T4 (22\%) as compared to T3 $(19 \%)$. Thus, while water tension (derived from the WRCs presented in Figure 4) in T1 and T2 reached $\mathrm{pF}$ values of 4.2 (permanent wilting point), in $\mathrm{T} 3$ and $\mathrm{T} 4$ these values were even higher, reaching $\mathrm{pF}$ values of 4.69 and 5.07, respectively. Finally, the water content differences between October and November were calculated, showing that water losses due to evapotranspiration and drainage in T1 $\left(37,053 \mathrm{~L} \mathrm{ha}^{-1}\right)$, 

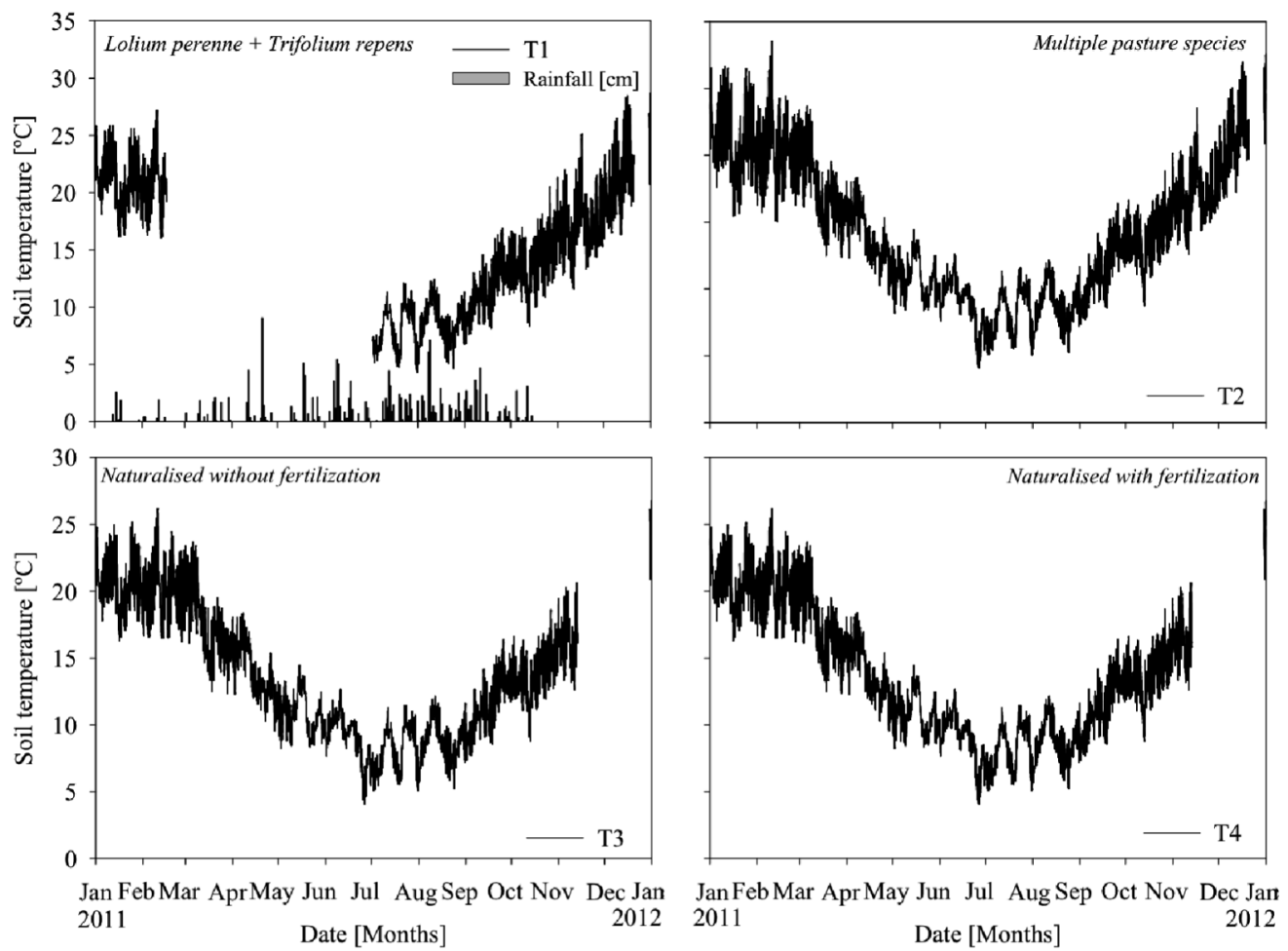

Figure 1. Soil temperature dynamics measured at the $10 \mathrm{~cm}$ depth for the studied pastures. In the figure corresponding to $\mathrm{T} 1$ the precipitation $(\mathrm{cm})$ is included.

T2 $\left(39,783 \mathrm{~L} \mathrm{ha}^{-1}\right)$, and T4 $\left(38,823 \mathrm{~L} \mathrm{ha}^{-1}\right)$ were clearly higher than those in T3 $\left(30,663 \mathrm{~L} \mathrm{ha}^{-1}\right)$.

\subsection{Soil physical properties}

The soil texture $($ sand $=16 \%$, silt $=63 \%$ and clay $=21 \%)$, as well as, the amount of organic matter $(14.4 \%)$ and particle density $\left(2.31 \mathrm{Mg} \mathrm{m}^{-3}\right)$ found in the studied soil are typical for this soil Serie (CIREN, 2003; Dec et al., 2012). Table 1 shows the penetration resistance (PR) before and after the first grazing event. The non-tilled plots, both before and after grazing, presented higher values than those registered in the tilled plots; whereas PR after grazing in T1, $\mathrm{T} 2$ and $\mathrm{T} 3$ was higher or the same as compared to the values before grazing, the opposite was observed in T4. The soil mechanical strength measured at the scale of soil horizon, group of aggregates and single aggregates is presented in Figure 3. In all treatments, the PR was greater than the aggregate strength (AS), and the latter was the same or even higher than the precompression stress $(\mathrm{Pc})$. On the other hand, after four grazing events and eight months after tillage (Table 1), minor differences determined by the Pc $(p>0.05)$ were observed between treatments, i.e., at the profile scale the PR was identical for all treatments, as was also found at the grouped aggregate scale. 

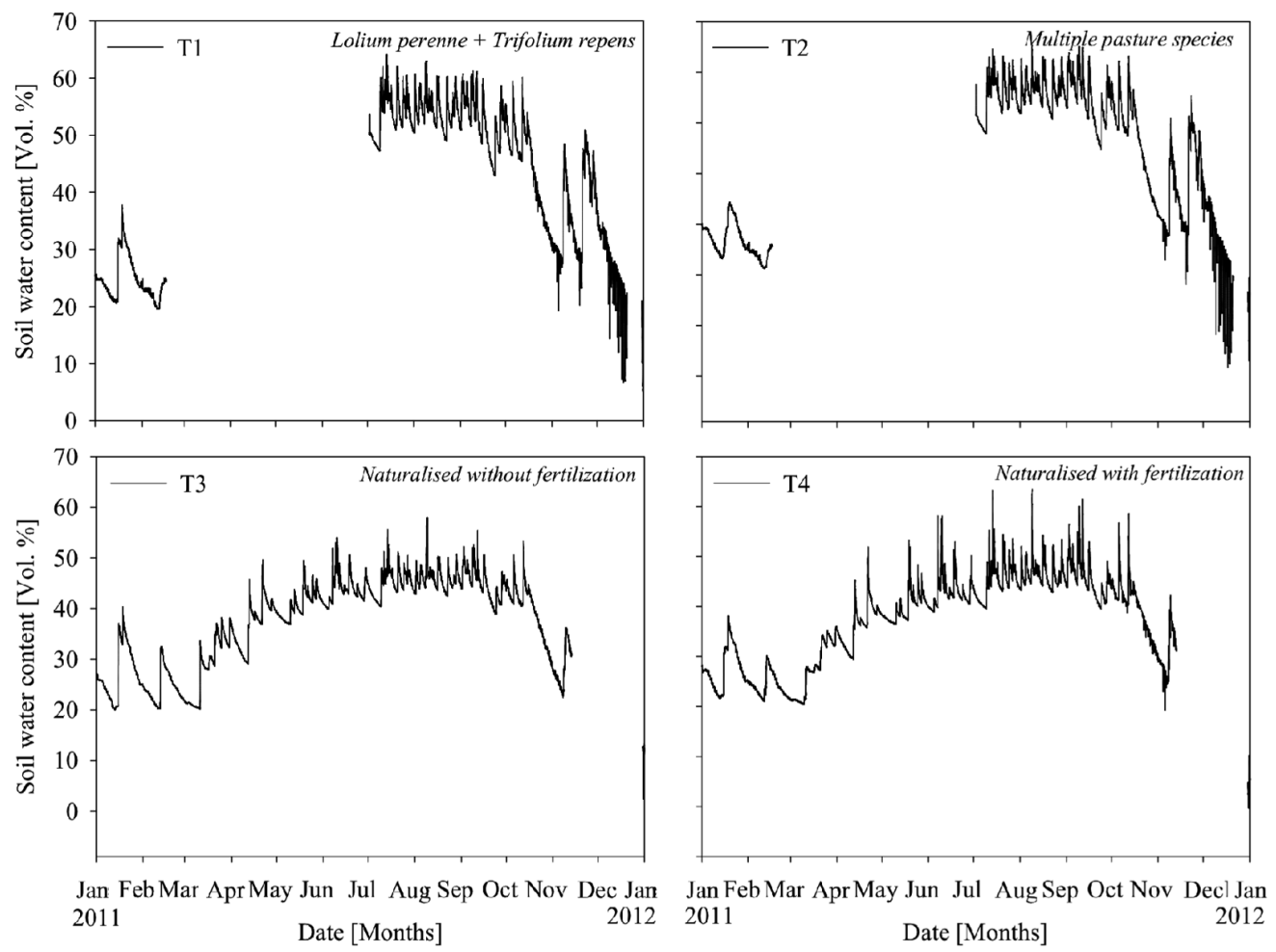

Figure 2. Water content dynamics measured at the $10 \mathrm{~cm}$ depth for the studied pastures.

The patterns created by the fitted WRCs differed between treatments (Figure 4), thus the van Genuchten parameters also showed differences as a consequence of the pasture improvement managements (PIM); i.e., whereas $\theta$ s and $n$ increased, $\alpha$ decreased (Table 2). The changes in the air capacity (AC) and plant available water (PAW) calculated from the water retention curves' measured values, are presented in Figure 5. When the initial situation (IS) was compared to all the treatments (T1-T4), the AC was found to decrease in the tilled soil $(\mathrm{T} 3>\mathrm{T} 4>\mathrm{T} 2=\mathrm{T} 1)$, while PAW increased $(\mathrm{T} 1>\mathrm{T} 2>\mathrm{T} 4=\mathrm{T} 3)$. Thus, both $\mathrm{T} 3$ and $\mathrm{T} 4$, which were not tilled, presented no significant differences compared to the IS in terms of AC and PAW $(p>0.05)$.
The air conductivity $\left(k_{l}\right)$ measured at the macropore level in the IS was observed to be higher than in the tilled plots $(p \leq 0.05)$ and almost the same as that found in T3 and T4 (Figure 6). At the same time, $k_{l}$ measured at both water potentials in both $\mathrm{T} 3$ and T4 was slightly higher (but not statistically significant) as compared to $\mathrm{T} 1$ and $\mathrm{T} 2$.

The relationship between air permeability $\left(k_{a}\right)$ and airfilled porosity $\left(\varepsilon_{a}\right)$ (Figure 7) was statistically significant for all treatments $(p \leq 0.05$, only one exception was observed in T4) with high $\mathrm{R}^{2}$ values (Table 3 ). This indicates that $k_{a}$ increased linearly while $\varepsilon_{a}$ increased. The pore-continuity parameters and blocked porosities $\left(\varepsilon_{b}\right)$ are presented in Table 3 . The $\varepsilon_{b}$ of the soil in T1 and 
$\mathrm{T} 3$ was greater than that observed in T4, IS and T2. T2 presented an unexpected low $\varepsilon_{b}$ value related to the very low $\mathrm{N}$ value (the lowest of all treatments). The continuity between pores was provided by $\mathrm{N}$, and the relationship between treatments was: T3>IS $>\mathrm{T} 1>\mathrm{T} 4>\mathrm{T} 2$. The porecontinuity was also studied using the $C^{2}$ and $C^{3}$ indices (Figure 5). As is also shown in Table 3, IS, T3 and T4 presented coefficient values greater than those found in the tilled pastures. Finally, the soil S-index (Table 2) derived from the adjusted WRC (Figure 4) presented the following relationship between treatments: $\mathrm{T} 1 \geq \mathrm{T} 2>\mathrm{T} 3=\mathrm{T} 4>\mathrm{IS}$.
When the S-index was correlated to the mechanical properties, it decreased with increasing mechanical strength. This was true for PR v/s S-index (r: $-0.79, p$ $\leq 0.01), \mathrm{Pc} v / \mathrm{s} \mathrm{S}$-index (r: $-0.70, p \leq 0.29)$ and AS v/s S-index ( $\mathrm{r}:-0.71, p \leq 0.29)$. The correlation between bulk density and the S-index (r: $-0.28, p \leq 0.65$ ), as well as, between organic matter and the S-index (r: $-0.40, p \leq 0.51)$ was very poor. However, when $C^{2}$ $\mathrm{v} / \mathrm{s}$ S-index (r: $-0.83, p \leq 0.08)$ and $C^{3} \mathrm{v} / \mathrm{s}$ S-index (r: $-0.91, p \leq 0.03)$ were correlated, significant negative relationships were once again found.

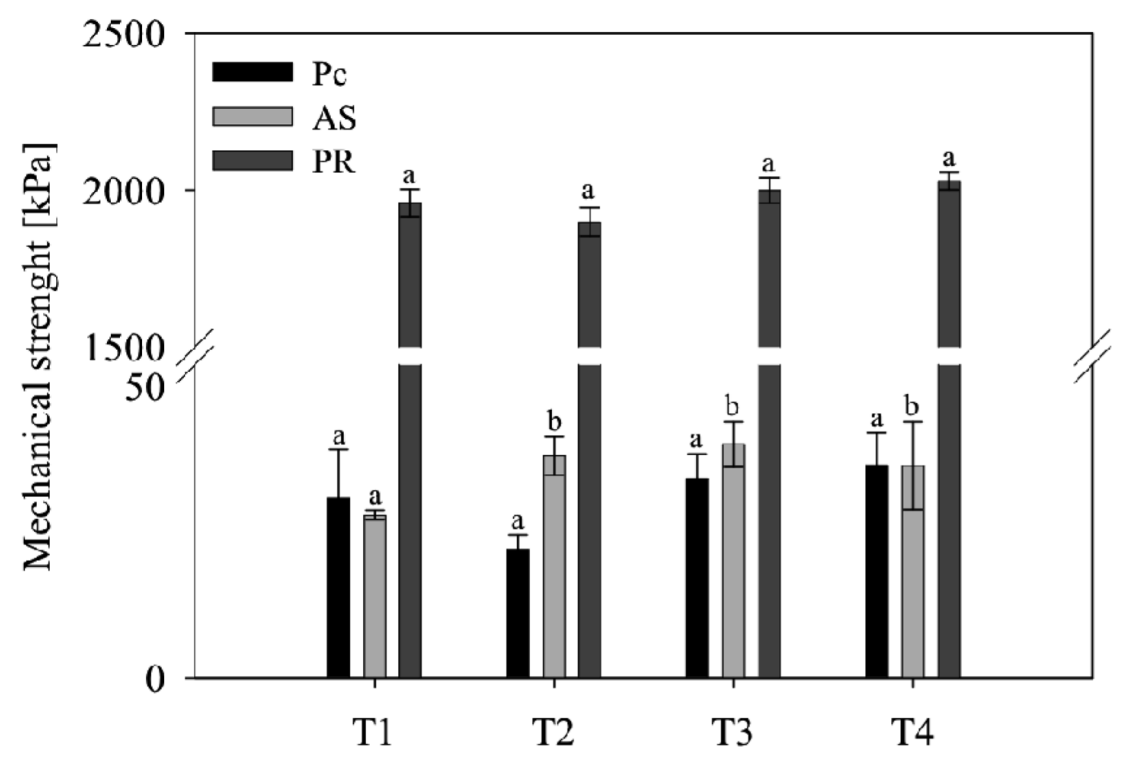

Figure 3. Soil mechanical strength as a function of pasture improvement managements. Pc: precompression stress, AS: aggregate strength, PR: penetration resistance. 

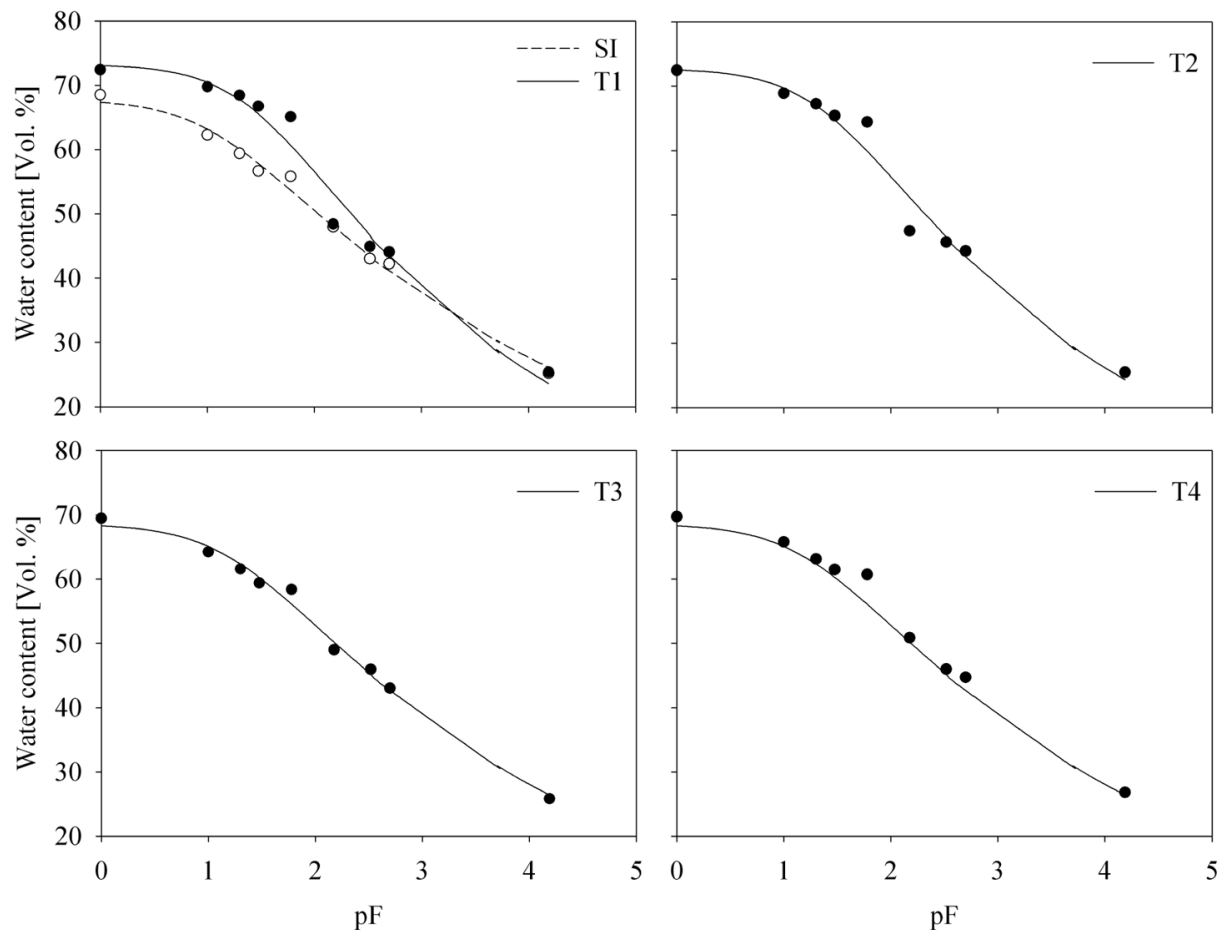

Figure 4. Water retention curves as a function of pasture improvement managements. The points are the measured values whereas the lines are the fitted curves according to van Genuchten's model (1980).

\section{Discussion}

\subsection{Pasture improvement effects on soil physical quality and transport processes}

While research has commonly focused on the effect of animal treading on soil compaction (Rezkowszka et al., 2011), little attention has been paid to the natural soil recovery (Drewry, 2006., Dec et al., 2012) and even less on the effect of different pasture improvement managements on soil physical quality, particularly, when the initial situation is a degraded pasture. Therefore, in the present work the soil physical quality (water and air holding capacities/conductivities and mechanical strength) and related processes (water content and temperature dynamics) were evaluated.

When the initial situation IS was compared to the soil hydraulic properties of both tilled soils and seeded pastures T1 and T2 (9 months after tillage), it was assessed that due to soil tillage and the consequent aggregate destruction, water (PAW) and air (AC) holding capacity functions (Figure 5), as well as the soil's ability to transport air ( $k_{l}$ in Figure 6) were affected, i.e. while PAW increased, $\mathrm{AC}$ and $k_{l}$ decreased. Similar soil behavior (but considering hydraulic instead of air conductivity) have previously been described by Ellies et al. (2000) in Andisols under different land 
Table 2. Van Genuchten parameters as a function of the pasture improvement managements.

\begin{tabular}{lllllll}
\hline Treatments & $\theta_{\mathrm{S}}$ & $\theta_{\mathrm{R}}$ & $\alpha$ & $\mathrm{n}$ & $\mathrm{R}^{2}$ & $\mathrm{~S}$ \\
& {$[\%]$} & {$[\%]$} & {$[-]$} & {$[-]$} & {$[-]$} & {$[-]$} \\
\hline IS & $67.8 \pm 1.2$ & 0 & $0.085 \pm 0.024$ & $1.133 \pm 0.008$ & 0.99 & 0.062 \\
T1 & $73.3 \pm 2.4$ & 0 & $0.036 \pm 0.018$ & $1.179 \pm 0.025$ & 0.97 & 0.084 \\
T2 & $72.8 \pm 2.4$ & 0 & $0.040 \pm 0.021$ & $1.170 \pm 0.024$ & 0.97 & 0.080 \\
T3 & $68.6 \pm 1.2$ & 0 & $0.057 \pm 0.016$ & $1.141 \pm 0.009$ & 0.99 & 0.065 \\
T4 & $69.1 \pm 1.1$ & 0 & $0.042 \pm 0.012$ & $1.146 \pm 0.011$ & 0.99 & 0.065 \\
\hline
\end{tabular}

$\theta_{\mathrm{S}}=$ saturated water content, $\theta_{\mathrm{R}}=$ residual water content, $\alpha$ and $\mathrm{n}=$ empirical parameters which describes the shape of the water retention curve (van Genuchten, 1980). S: Index of soil physical quality according to Dexter (2004).

uses, in a Chernozem under different tillage systems by Schwen et al. (2011) and in a tilled Andosol by Dörner et al. (2012). All this works, however, were mainly focused on soil physical degradation. In the present study, soil tillage breaks up aggregates, decreasing the pore-continuity at the macropore scale as assessed by $C_{2}$ and $C_{3}$ at a water potential of $-6 \mathrm{kPa}$ (Figure 8). This is normally true since macropores are the first to be modified in volume and organization when the soil is exposed to an external stress (at least four grazing events were conducted before sampling). Similar results, in Dörner et al. (2012), described the temporal dynamics of soil structure of a tilled Andisol and assessed that macropores are strongly affected by mechanical and hydraulic stresses. Therefore, the short-term effects of tilling on this soil to improve its pasture's quality resulted in an increased water holding capacity (Figure 3), decrease in air capacity (Figure 3) and pore-continuity values (Figure 8 ) after grazing.
The pasture improvement managements analysed here considered fertilized-tilled (T1 and T2) and fertilized non-tilled (T4) plots, which were compared to nonfertilized-tilled (T3) ones. In general, the non-tilled but grazed plots (T3 and T4) behaved similarly to the IS, e.g. the air capacity and conductivity, as well as the pore continuity of $\mathrm{T} 3$ and $\mathrm{T} 4$ were close to the values observed in the IS. Therefore, soil tillage helped T1 and T2 improve the amount of PAW, however, the amount of pores responsible for gas exchange (air capacity) were partially lost, reaching critical values $(<8 \%)$ (Horn and Fleige, 2009). Soil tillage normally implies an increase of macropores (Dörner et al., 2012). However, the soil becomes unstable after natural soil consolidation due to wetting-drying cycles (Dörner et al., 2012), which is even greater after grazing events. This human (soil tillage, grazing) and naturally induced (wetting-drying cycles) soil deformation are the causes for a decrease in the soil air and an increase for the water holding capacity. 

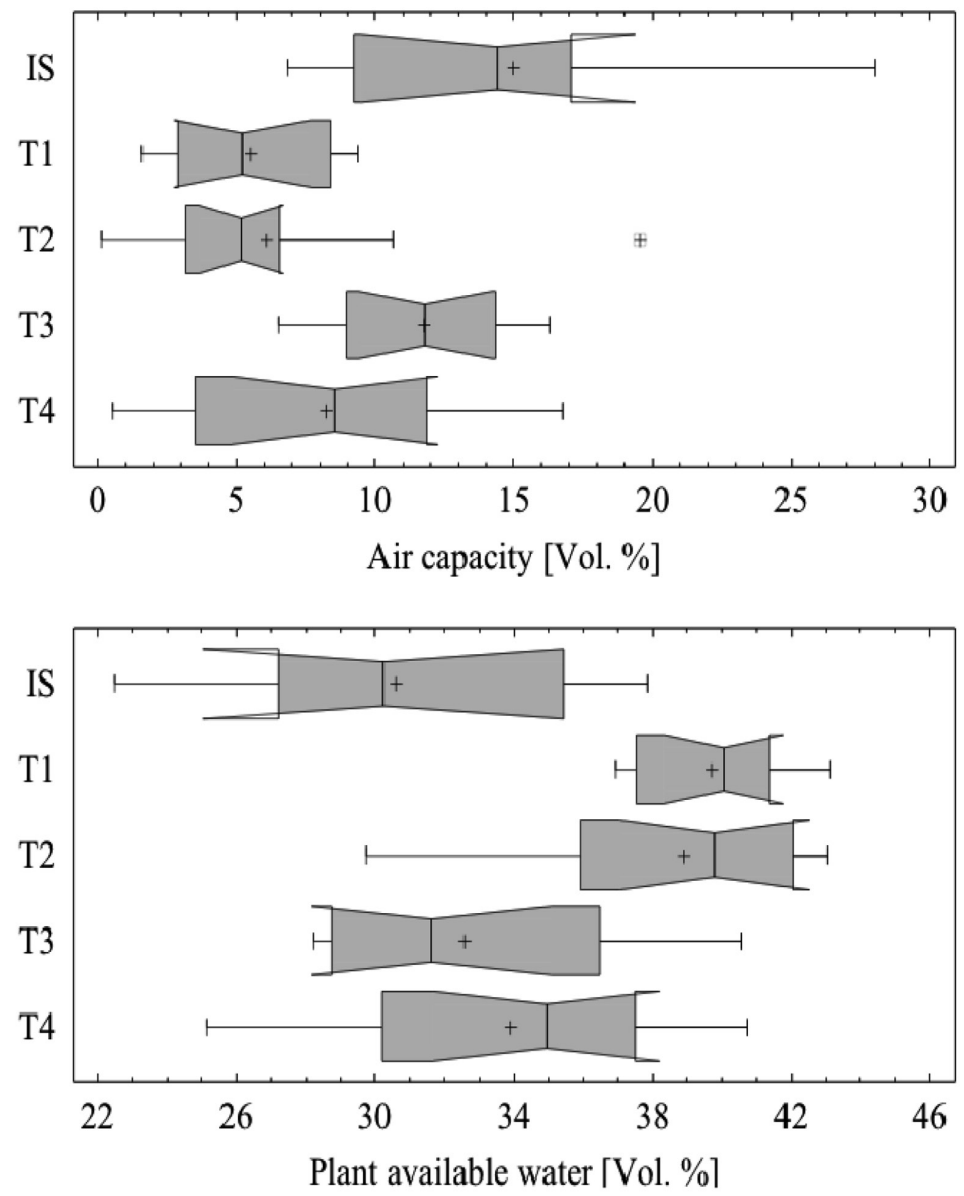

Figure 5. Air capacity (AC) and plant available water (PAW) as a function of pasture improvement managements. The characteristics of the box plot analysis are in the statistics section. 
This behaviour, which has also been described in Andisols under pastures (Dec et al., 2012) and crops (Dörner et al., 2012), was also confirmed by the results of PR. The PR values before grazing (Table 1) were lower for $\mathrm{T} 1$ and $\mathrm{T} 2$ as compared to $\mathrm{T} 3$ and $\mathrm{T} 4$. As expected, the tilled soils were mechanically unstable than the non-tilled ones, since the soil structure was destroyed after tillage. However, as soon as, wettingdrying cycles occured and grazing events were conducted, the tilled soil reached a higher level of mechanical stabilization and minor differences in soil strength were observed among treatments. Although this increase in mechanical stability was reached, it was due to a decrease in air capacity (Figure 3), conductivity (Figure 6) and derived pore-continuity values (Figure 7 and 8).

The S-Index (Dexter, 2004) was used to evaluate the soil physical quality. The $\mathrm{S}$ value is an indicator of the extent to which the soil porosity is concentrated into a narrow range of pore sizes. Larger $\mathrm{S}$ values are normally related to the presence of a better-defined microstructure responsible for soil physical properties that are necessary for the proper functioning of soil (Dexter, 2004). Observed S values (>0.035) reflect a good soil structural quality, which is in agreement with the excellent physical properties which have been described for Andisols by many authors (Dörner et al., 2012, Baumgarten et al., 2013). In fact in the present study, S values were between 0.062 and 0.084 for a soil with bulk densities $<0.9 \mathrm{Mg} \mathrm{m}^{-3}$, which are typical for well-aggregated volcanic soils (Dörner et al., 2012) and larger than those presented by Dexter (2004) for soils with similar particle size distribution, but larger bulk densities and lower amounts of organic matter. Finally, tillage increased the soils' $\mathrm{S}$ values, which reflects a decrease in the mechanical strength (e.g., lower PR) and the presence of higher PAW but less connected pores as represented by a lower $k_{l}$.

The observed changes in the soil structure affected the soil physical quality in terms of capacity (AC and PAW) and intensity ( $k_{l}$ and $k_{s}$ ) parameters. Thus, affecting soils' transport processes (Horn and Fleige,
2009). The soil water contents (Figure 2) were in agreement with the $\theta$ s-values and WRC (Figure 4 and Table 2), i.e. a greater water holding capacities for $\mathrm{T} 1$ and $\mathrm{T} 2$ resulted in higher water contents during wintertime. The water content presented dynamic changes inducing wetting-drying cycles, which improved the soil structure (Dörner et al., 2012), also affecting the soil properties (when the water content increased the mechanical strength decreased). In all treatments an intense soil drying was observed as soon as the temperature increased and rainfalls decreased in October (Figure 1). The improvement on water holding capacity of the tilled plots was observed both in the WRC and water content dynamics measured in the field, i.e. during the first intense drying only the non-tilled soils greatly exceeded the permanent wilting point ( $\mathrm{pF}$ 4.2). This difference in PAW affected the treatments' pasture productivity; in fact, the water lost (mainly due to evapotranspiration) between October and November was positively related to the dry matter production in the spring (Flores et al., 2013) (r: 0.92; $p<0.08$ ).

Finally, differences in the mean values of the soil temperature measured at the same depth among treatments were assessed, i.e. the mean annual temperatures of $\mathrm{T} 1$ and $\mathrm{T} 2$ were slightly higher than those of T3 and T4. This can be ascribed to: i) different thermal properties as a consequence of soil tillage and ii) the insulation effect of plant residues. The tilled plots presented the highest water contents, since soil thermal diffusivity depends on the soil water content (Gan et al., 2012). The higher average temperatures of the tilled soils could be a response of the higher thermal diffusivity. Nonetheless, the insulating effect of the residues cannot be neglected. It is well known that in pastures vegetation residues are good temperature insulators (Gan et al., 2012). Therefore, the lower temperatures at the $10 \mathrm{~cm}$ depth in $\mathrm{T} 3$ and $\mathrm{T} 4$ could also be a consequence of the presence of more than $20 \%$ of broadleaf species (e.g. Hypochaeris radicata), which may induced lower temperatures throughout the year. 

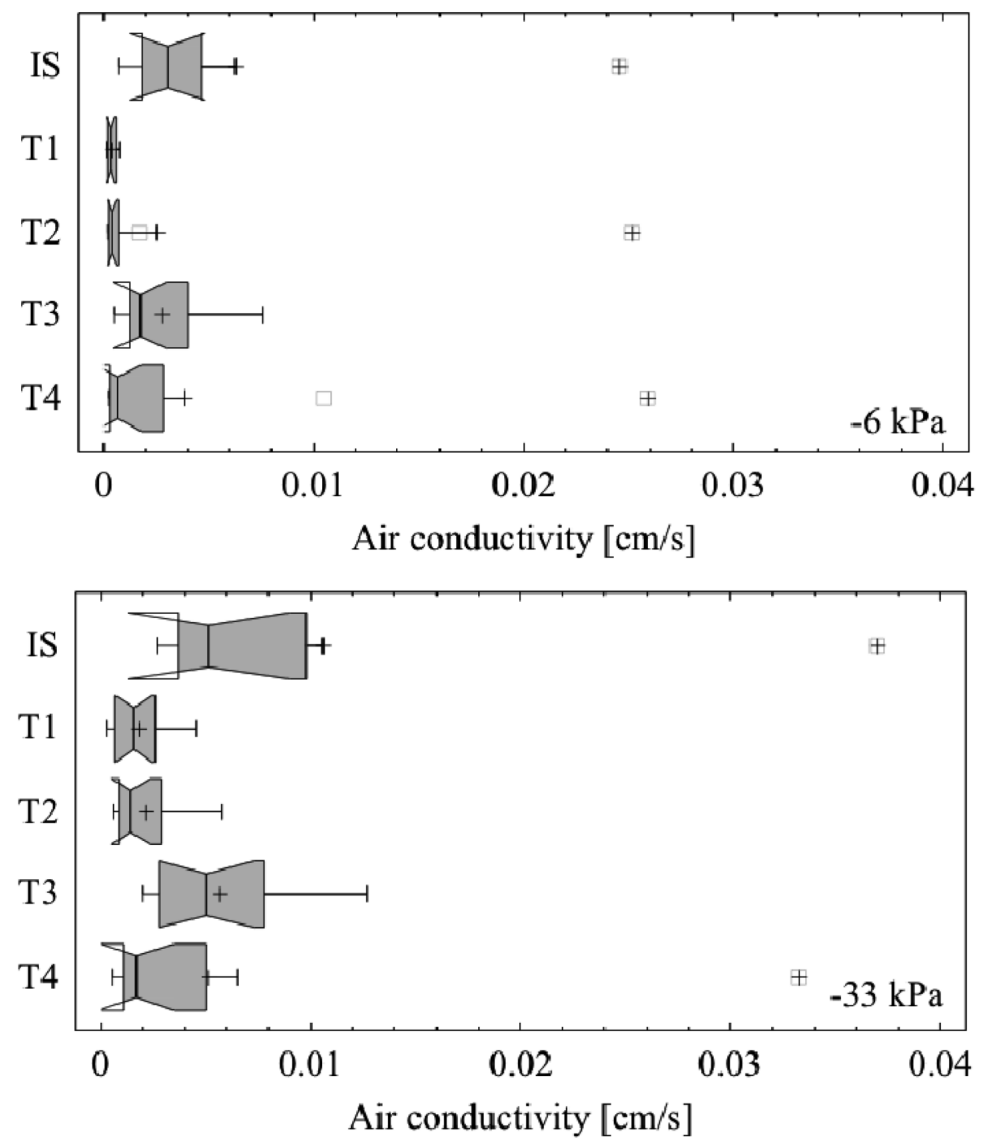

Figure 6. Air conductivity ( $k_{l}$, measured at -6 and $-33 \mathrm{kPa}$ of water potential) as a function of pasture improvement managements. The characteristics of the box plot analysis are in the statistics section. 

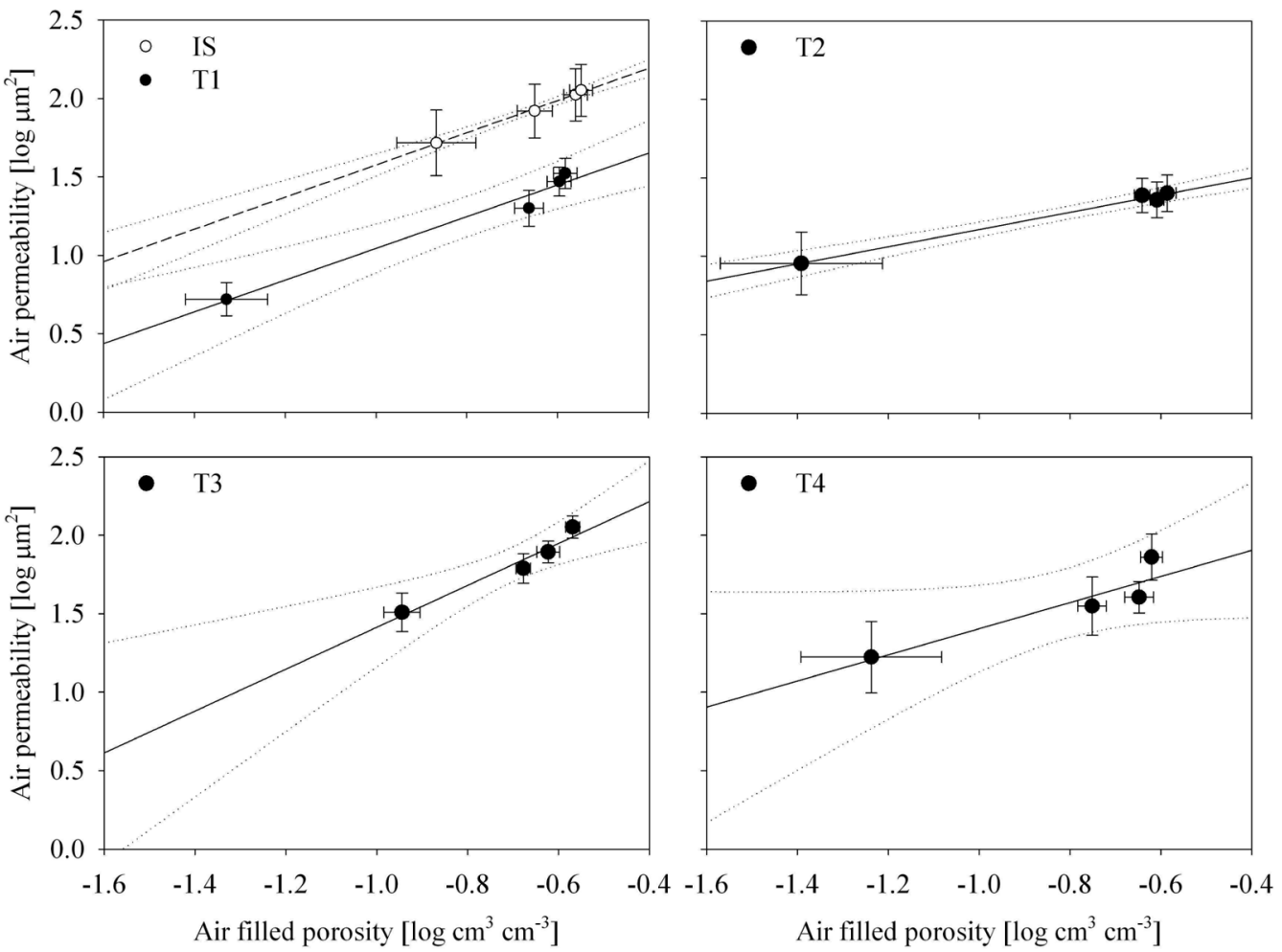

Figure 7. Relationship between air permeability $\left(k_{a}\right)$ and air-filled porosity $\left(\varepsilon_{\mathrm{a}}\right)$ for the different pasture improvement managements. The linear regression was conducted according to equation 4. Bars indicate \pm standard error (n: 21). 

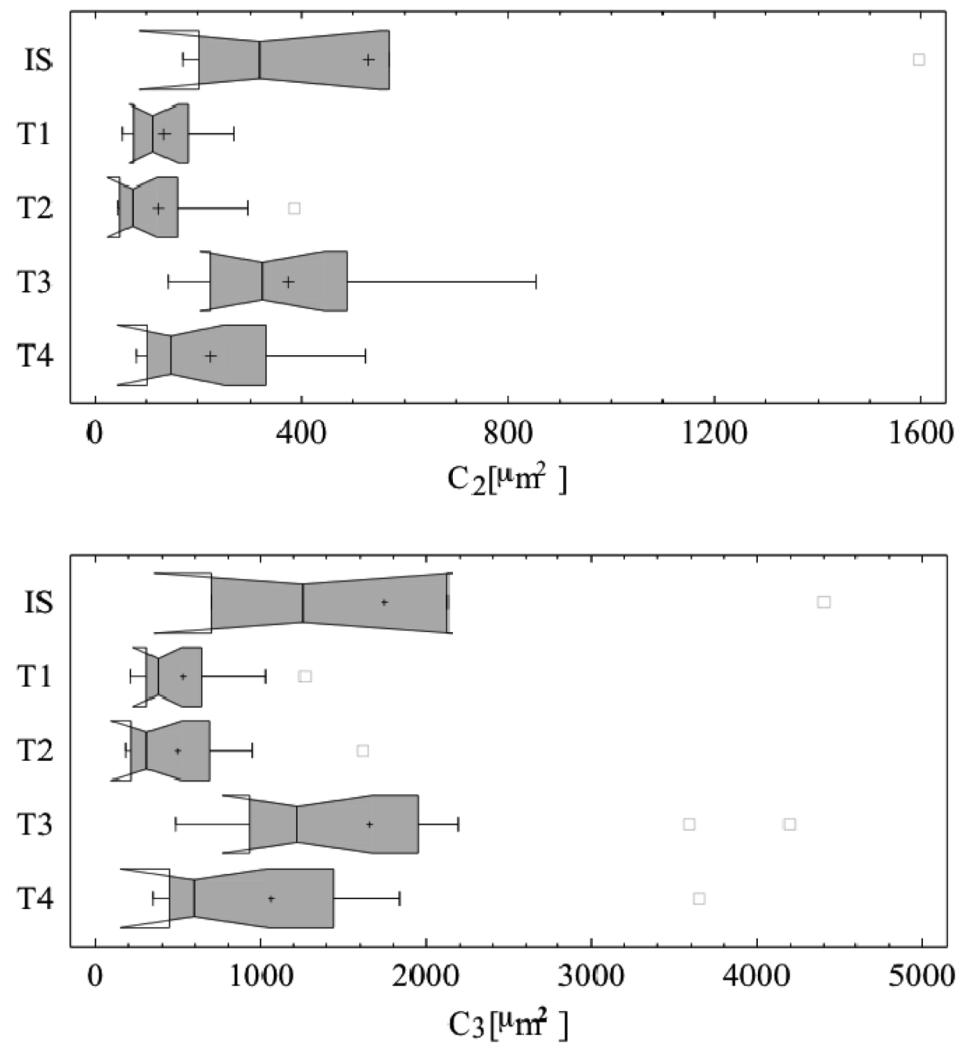

Figure 8. Pore continuity indices for the studied pastures. The characteristics of the box plot analysis are in the statistics section. 
Table 3. Regression parameters ( \pm standard error) and blocked porosities according to equations 4 and 5 .

\begin{tabular}{lllll}
\hline Treatments & Log $M$ & $N$ & $R^{2}$ & $\varepsilon_{\mathrm{b}}$ \\
& {$[-]$} & {$[-]$} & {$[-]$} & [Vol. \%] \\
\hline IS & $2.601 \pm 0.037$ & $1.025 \pm 0.055$ & $0.99^{* * *}$ & 0.29 \\
T1 & $2.055 \pm 0.101$ & $1.011 \pm 0.118$ & $0.96^{* *}$ & 0.93 \\
T2 & $1.179 \pm 0.031$ & $0.548 \pm 0.035$ & $0.99^{* * *}$ & 0.07 \\
T3 & $2.751 \pm 0.157$ & $1.336 \pm 0.219$ & $0.95^{* *}$ & 0.87 \\
T4 & $2.238 \pm 0.217$ & $0.833 \pm 0.254$ & $0.84^{*}$ & 0.21
\end{tabular}

${ }^{*} p \leq 0.1 ;{ }^{* *} p \leq 0.05 ;{ }^{* *} p \leq 0.01$

\section{Conclusions}

The pasture improvement managements PIM, affected the soil physical quality and related processes differently in short-term. The soil structure was destroyed after tillage, decreasing the penetration resistance of tilled plots as compared to non-tilled plots. However, as soon as wetting-drying cycles occurred and grazing events were conducted, the tilled soil reached a higher mechanical strength, although minor differences were observed among treatments. The aggregate destruction after tillage induced in short term an increase in the water holding capacity and a decrease of the air capacity and pore-continuity values due to grazing as compared to non-tilled plots.

The physical quality assessed by the S-index reflects a good soil structural quality $(S>0.035)$, which confirms the good physical properties of volcanic ash soils. In fact, after nine months of imposed PIM, the tilled plots presented a higher S-index as compared to non-tilled plots, which is related to a slightly lower mechanical strength and larger water holding capacity. The soil water content and temperature dynamics also responded to the implemented PIM. Soil structure changed as a consequence of tillage as assessed by the water holding capacity, measured by the water retention curves. This was also confirmed by the water content recorded in the field. The soil water holding capacity during the first intensive soil drying was positively correlated to the pasture yield. Soil temperature differences assessed amongst treatments could be related to both: higher water contents in the tilled plots and the presence of broadleaf species in the non-tilled pastures. Finally, long-term studies are required to understand how the implementation of pasture improvement managements affects the soil physical quality and related processes. 


\section{Acknowledgements}

FONDECYT Project 1100957 "Sustainable pasture improvement and its relationship to soil quality" sponsored the present study. The second author gives thanks for the financial support to conduct his Magister en Ciencias del Suelo (Escuela de Graduados, Facultad de Ciencias Agrarias, Universidad Austral de Chile).

\section{References}

Amigo, J., Ramírez, C. 1998. A bioclimatic classification of Chile: woodland communities in the temperate zone. Plant Ecology. 136, 9-26.

Amtmann, C., Mujica, F., Vera B. 1999. Small scale agriculture in the Los Lagos Region, Chile. Ediciones Universidad Austral de Chile, Chile.

Ball, B.C., O‘Sullivan, M.F., Hunter, R. 1988. Gas diffusion, fluid flow and derived pore continuity indices in relation to vehicle traffic and tillage. J. Soil Sci. 39, 327-339.

Balocchi, O., López, I. 2007. Improving naturalised pastures in the South of Chile. In: Hervé, M. Producción Ovina: Desde el Suelo a la Gestión. Ministerio de Agricultura, Gobierno de Chile, pp 13-21.

Baumgarten, W., Horn, R., Dörner, J. 2013. Microstructural Development in Volcanic Ash Soils from South Chile. Soil Till. Res. 129, 48-60.

Baumgartl, T., Köck, B. 2004. Modeling volume change and mechanical properties with hydraulic models. Soil Sci. Soc. Am. J. 68, 57-65.

Butler L. D., Cropper J. B., Johnson R. H., Shaver P. 1997. National range and pasture handook. United States Department of Agriculture,
Natural Resources Conservation Service and Grazing Lands Technology Institute. USA.

CIREN (Centro de Información de Rercursos Naturales). 2003. Estudio agrológico X Región. Tomo 1. 199 p.

Day, P.R. 1965. Particle fractionation and particle size analysis. In: Black, C.A., et al. (Ed.), Methods of soil analysis, Part I: Agronomy, 9, pp. 545-567.

Dec, D., Dörner, J., Balocchi, O., López, I. 2012. Temporal dynamics of hydraulic and mechanical properties of an Andosol under grazing. Soil Till. Res. 125, 44-51.

Delta-T Devices Ltda. 2006. User Manual for the SM200 Soil Moisture Sensor. Delta-T Devices Ltda, Cambridge, UK, p. 36.

Dexter, A.R. 1988. Advances in characterization of soil structure. Soil Till. Res. 11, 199-238.

Dexter, A.R. 2004. Soil physical quality Part I. Theory, effects of soil texture, density, and organic matter, and effects on root growth. Geoderma. 120, 201-214.

Dörner, J., Horn, R. 2006. Anisotropy of pore functions in structured Stagnic Luvisols in the weichselian moraine region in N Germany. J. Plant Nutr. Soil Sci. 169, 213-220.

Dörner, J., Dec, D., Feest, E., Vásquez, N., Díaz, M. 2012. Dynamics of soil structure and pore functions of a volcanic ash soil under tillage. Soil Till. Res. 125, 52-60.

Drewry, J. 2006. Natural recovery of soil physical properties from treading damage of pastoral soils in New Zealand and Australia: A review. Agr, Ecosyst. Environ. 114, 159-169.

Ellies, A., Horn, R., Smith, R. 2000. Effect of management of a volcanic ash soil on structural properties. In. Agrophysis. 14, 377-384. 
Flores, P., López, I. F., Kemp, P. D., Dörner, J. 2013. Tiller Population Dynamics and Competition Between Lolium perenne L. and Agrostis capillaris L. as Response to Fertilizer Addition in Naturalized Pasture in Valdivia Chile. Proceedings and Abstracts, American Forage and Grassland Council (AFGC), Annual Meeting, January 6 - 9, Covington, KY.

Gan, L., Peng, X., Peth, S., Horn, R. 2012. Effects of grazing intensity on soil thermal properties and heat flux under Leymus chinensis and Stipa grandis vegetation in Inner Mongolia, China. Soil Till. Res. 118, 147-158.

Greenwood, K., McKenzie, B. 2001. Grazing effects on soil physical properties and the consequences for pastures: a review. Aust. J. Exp. Agr. 41, 12311250.

Groenevelt, P.H., Kay, B.D., Grant, C.D. 1984. Physical assessment of a soil with respect to rooting potential. Geoderma. 34, 101-114.

Havlin J.L., Beaton J.D., Tisdale S.L., Nelson W.L. 2005. Soil fertility and fertilizers: An introduction to nutrient management. Pearson Education, Inc., New Jersey, USA.

Horn, R., Fleige, H. 2009. Risk assessment of subsoil compaction for arable soils in Northwest Germany at farm scale. Soil Till. Res. 102, 201-208.

Horn, R., Kutilek, M. 2009. The intensity-capacity concept-How far is it possible to predict intensity values with capacity parameters. Soil Till. Res. 103, $1-3$.

INE (Instituto Nacional de Estadísticas). 2007. Censo agropecuario y forestal 2007. Resultados por comuna (on line)http://www.ine.cl/canales/ chile_estadistico/censos_agropecuarios/censo_ agropecuario_07_comunas.php.
Klute, A. 1986. Methods of soil analysis. Part 1: Physical and mineralogical Methods. 2nd ed. SSSA Book Ser. 5. SSSA, Madison, WI.

López, I., Balocchi, O., Lailhacar, P., Oyarzún, C. 1997. Caracterización de sitios de crecimiento de seis especies pratenses nativas y naturalizadas del Dominio Húmedo de Chile. Agro Sur. 25, 62-80.

Reszkowska, A., Krümmelbein, J., Peth, S., Horn, R., Zhao, Y., Gan, L. 2011. Influence of grazing on hydraulic and mechanical properties of semiarid steppe soils under different vegetation type in Inner Mongolia, China. Plant Soil. 340, 59-72.

Reynolds, W.D., Drury, C.F., Tan, C.S., Fox, C.A., Yang, X.M. 2009. Use of indicators and pore volume-function characteristics to quantify soil physical quality. Geoderma. 152, 252-263.

Schwen, A., Bodner, G., Scholl, P., Buchan, G.D., Loiskandl, W. 2011. Temporal dynamics of soil hydraulic properties and the water-conducting porosity under different tillage. Soil Till. Res.113, 89-98.

van Genuchten, M.T. 1980. A closed-form equation for predicting the hydraulic conductivity of unsaturated soils. Soil Sci. Soc. Am. J. 44, 892-898.

Walkley, A., Black, I.A. 1934. An examination of the Degtjareff method for determining soil organic matter and a proposed modification of the chromic acid titration method. Soil Sci. 37, 29-38. 